\title{
Evaluation of Yield Performance of Mustard (Brassica juncea) through Cluster Front Line Demonstration
}

\author{
Hrish Kumar Rachhoya*, Mukesh Sharma and Kana Ram Sodh
}

Krishi Vigyan Kendra, (GVM), Sardarshahar District-Churu -1 (Rajasthan), India-334003

*Corresponding author

A B S T R A C T

\begin{tabular}{|l|}
\hline Ke y w o r d s \\
$\begin{array}{l}\text { Cluster Front Line } \\
\text { Demonstration } \\
\text { (CFLD), }\end{array}$ \\
$\begin{array}{l}\text { Intervention, } \\
\text { Technology, Yield } \\
\text { and mustard }\end{array}$ \\
\hline Article Info \\
\hline $\begin{array}{l}\text { Accepted: } \\
\text { 06 June } 2018 \\
\text { Available Online: } \\
\text { 10 July } 2018\end{array}$ \\
\hline
\end{tabular}

\section{Introduction}

India is among the largest vegetable oil economies in the world. The contribution to the agricultural economy of India ranks second only to food grains. India is the third largest rapeseed-mustard producer in the world after China and Canada with 12 per cent of world's total production (2006-07). This crop accounts for nearly one-third of the oil produced in India, making it the country's key edible oilseed crop. Suitable agro-climatic conditions favor cultivation of all nine major oilseed crops. The oilseeds account for nearly
$3 \%$ of the gross national product and 10 percent of the value of all agricultural products. More than $80 \%$ of the total oilseed acreage and production is covered by the states of Madhya Pradesh, Rajasthan, Maharashtra, Gujarat, Andhra Pradesh and Karnataka. Rapeseed-mustard comprises a group of cultivated oilseed Brassicas of tribe Brassicae within the family Brassicaeae.The mustard production scenario in the country has undergone a sea change. The main contributors to such transformations have been availability of improved oilseeds production technology and its adoption, expansion of 
cultivated area, price support policy and institutional support, particularly establishment of technology mission on oilseeds in 1986 (Hegde, 2004). The improved technology packages were also found to be financially attractive. Yet, adoption levels for several components of the improved technology were low, emphasizing the need for better dissemination (Kiresur et al., 2001). Several biotic, abiotic and socio-economic constraints inhibit exploitation of the yield potential and these needs to be addressed. The state-wise yields obtained both under improved technology and farmers' practice ranges from 12 to $110 \%$ between states and the National average being $36 \%$. The additional production that can be attained by exploiting the yield gap at national level is about 2 million tonnes (Kumar and Chauhan, 2005). Rajasthan has the sizeable area (ha) under mustard cultivation with total with the productivity level is low $(\mathrm{kg} / \mathrm{ha}$ ) as compared to other states like Haryana $(1738 \mathrm{~kg} / \mathrm{ha})$ during $2014-15$. Therefore, keeping the above point in view, the CFLDs on mustard using integrated crop management technology was started with the objectives of showing the productive potentials of the new production technologies under real farm situation over the locally cultivated mustard crop.

In general the productivity of gram crop in Churu is low because of least technological backup, small and marginal land holdings and poor adoption of improved package of practices. Therefore, efforts have been made through Cluster Front Line Demonstrations (CFLDs) to introduce innovative package of practices of gram with a view to increase its productivity in the district. So, the present investigation has been undertaken with following objectives.

1. To evaluate the impact of Cluster Front Line Demonstration on yield enhancement of mustard.
2. To investigate the impact of Cluster Front Line Demonstration on technology adoption. 3. To find out the role of technology in minimizing the disease and insect infestation.

\section{Materials and Methods}

Study was carried out by Krishi Vigyan Kendra and 250 demonstrations were conducted in its adopted village's viz. Dhingli, Sulakiniya Chota, Sulakiniya Bada, Swai Delna, Parawada, Dhani Suhana, Pabusar, Lachasar, Malsar, Malaksar and Ladasar of Churu district of Rajasthan in Rabi season of 2015-16,2016-17 and 2017-18 on the selected farmers' fields. Each demo was conducted in 0.4 ha (one acre) and thus, 250 demonstrations were conducted 2015-16 to 2017-18 year. For the adoption of village PRA technique and for the selection of farmers the purposive sampling design from frequently organized group meetings was exercised in each village. Before conducting CFLDs, a list of sample farmers was prepared. Package of practices (POP) oriented training to be imparted to the selected farmers (Venkattakumar et al., 2010). During meeting, receptive and innovative farmers were selected for technological intervention. Improved technology released from SKRAU Bikaner was adopted, which was comprised of soil test based fertilizers tailoring (92:32:0:40 kg NPKS ha-1), seed treatment (Apron $6 \mathrm{~g} \mathrm{~kg}-1$ seed followed by Azotobactor and PSB culture @ 600 g ha-1 seed), soils treatment (Trichoderma harzyanum culture @05 $\mathrm{kg} \mathrm{ha}^{-1}$ ), Disease resistant variety NRCDR-02, Seed (@ 4kg ha ${ }^{1}$ ), sowing time (first fort night of October), sowing by Seed cum fertilizer drill, sowing distance ( $30 \mathrm{~cm} \mathrm{R}$ to $\mathrm{R}$ ), weed management, harvesting (between last week of March to first week of April). In general the soil in which CFLDs were conducted having $\mathrm{PH}$ range of 7.52-8.22, EC 0.4-0.7 $\mathrm{dSm}^{-1}$, organic carbon, phosphorus and potassium whose ranges were $0.21-0.34,47-52$ and $>282 \mathrm{~kg}$ hal 
respectively. Soils come under arido soil order and defined as medium sandy soils. The performance of demonstrated technology was compared with farmers practice in the same villages. Farmers' practice included imbalance use of fertilizers i.e. 18:46:0:0 kg NPKS ha-1, higher seed rate (6-7 $\mathrm{kg}$ ha-1) and indiscriminate use of pesticides. The differences in between demonstrated technology and existing farmers' practices (local check) are mentioned in table 1.

To study the yield attributes, 25 plants were selected by randomly placing of quadrate at five places in demo plots as well as in FPs plots and five plants selected from each quadrate. Yield data from demonstration and FPs' were collected after harvesting the crop. For the recording of seed index 100 seeds were taken and weighed. Economical assessment was done as per prevailing market prices. Data were collected from both demos as well as farmers' practice plots and analyzed for the yield gap, yield index (Samui et al., 2003).

\section{Results and Discussion}

\section{Yield}

Implementation of improved production technology remarkably increased the yield (19.56-32.62 \%) over farmers' practice during the three year of demonstration. The average yield under recommended practice was achieved $1666 \mathrm{~kg} \mathrm{ha}^{-1}$ as compared to the farmers' practice $1147 \mathrm{~kg} \mathrm{ha}^{-1}$ which was $24.72 \%$ higher (table-2). Although yield obtained under demo plots was lower than the potential yield of variety. It may be due to cumulative effect of several biotic and abiotic factors in micro climatic conditions that varying year to year. Yield enhancement under recommended practice might be due to balance nutrition as per soil test value, integrated approach, involving fertilizers and bio-fertilizers which play a vital role in making availability of plant nutrients. Similar results were observed by Tomar et al., (2003), Tiwari and Saxena (2001) and Tiwari et al., (2003). Data presented in table 2 revealed that demonstrated technology had impact over farmers' practices. It might be due to cumulative effect of yield attributes and seed index. The yield increased in demonstrated field due to technological intervention may happen in other similar situation. The results are in agreement with the findings as reported by Tomar et al., (2003).

\section{Economical assessment:}

The cost of cultivation in demonstration was comparatively higher (Rs. 22081-21820) as compared to farmers' practice (Rs.1945020651) because of additional input applied in demonstration. The gross return (Rs. 40586) and net returns (Rs. 21199) in farmer practice were lower than the gross return (Rs. 58029) and net returns (Rs. 37067) of demonstration. Average of gross and net returns of demonstration was $42.97 \%$ and $74.85 \%$ higher than that of farmers' practice respectively. It showed that the adoption of demonstrated technology by the farmers would be economically gainful proposition.

The $\mathrm{B}: \mathrm{C}$ ratio exhibited the same trend as in gross and net returns which was found 2.06 2.96 in demonstration and $1.78-2.17$ in farmers' practice (table 3). Year to year ups and downs in cost of cultivation, which consequently reflected the benefits were on account of variability in cost of inputs and outputs. Results suggested economic viability and agronomic feasibility of the technology for mustard cultivation. These results are in conformity of the results as reported by Deshmukh et al., (2005).

\section{Disease incidence}

Data recorded on plants infested with wilt (Fusarium wilt) caused by Fusarium revealed 
that, incidence of disease was lower in demonstration plot as compared to farmers' practice. It was observed that on an average only 4.36 plants M-2 showed wilting symptoms in demonstrations compared to 6.96 (average) plants M-2 in farmers' practice. Data presented in table 4 reflected that the percentage of damaged plant (9.74) was lower in demonstration as compared to farmers' practice (17.15). This could be ascribed due to seed treatment. The findings are in line with the results reported by Chand and Khirbat (2009) and Nene et al., (1978).

Table.1 Comparison between technological intervention and local check under CFLDs on musta

\begin{tabular}{|c|c|c|c|c|}
\hline $\begin{array}{l}\text { S. } \\
\text { No }\end{array}$ & Particulars & Technological Intervention (Demonstration) & Farmers Practice (Local Check) & Technological Gap \\
\hline 1 & Farming situation & Irrigated & Irrigated & No gap \\
\hline 2 & Variety & NRCDR-02 & Unidentified & Full gap (100 \%) \\
\hline 3 & Land preparation & $\begin{array}{l}\text { Summer deep ploughing followed by } \\
\text { rotavator }\end{array}$ & $\begin{array}{l}\text { Summer deep ploughing followed } \\
\text { by rotavator }\end{array}$ & No gap \\
\hline 4 & Time of sowing & First forth night of October & First forth night of October & No gap \\
\hline 5 & Seed treatment & Apron 6gkg-1 seed+ Bio-fertilizers & No seed treatment & Full gap $(100 \%)$ \\
\hline 6 & Seed rate & 4 kg ha-1 & 6-7 kg ha-1 & $\begin{array}{l}15-30 \% \text { more than } \\
\text { recommendation }\end{array}$ \\
\hline 7 & Method of sowing & Line sowing & Broadcasting sowing & No gap \\
\hline 8 & Nutrients application & 92:32:20:40 kg NPKS ha-1 & 16:46:0:0 kg NPKS ha-1 & $\begin{array}{l}\text { Not as per } \\
\text { recommendation }\end{array}$ \\
\hline 9 & Weed management & Manual weeding & Manual weeding & No gap \\
\hline 10 & Aphid control & Applied Dimethoate 30 EC @ 1200 ml/ha & $\begin{array}{l}\text { Use of indiscriminate and non } \\
\text { recommended insecticides }\end{array}$ & Full gap (100 \%) \\
\hline
\end{tabular}

Table.2 Performance of technological intervention (CFLDs) on yield and yield attributes of mustard

\begin{tabular}{|c|c|c|c|c|c|c|c|c|c|}
\hline \multirow[t]{2}{*}{ Year } & \multirow[t]{2}{*}{ Variety } & \multirow{2}{*}{$\begin{array}{c}\text { Yield } \\
\text { Potential } \\
\text { (Kg ha-1) }\end{array}$} & \multicolumn{2}{|c|}{$\begin{array}{l}\text { Plant Population } \\
\text { (No/M2) }\end{array}$} & \multicolumn{2}{|c|}{$\begin{array}{l}\text { Seed yield } \\
(\mathrm{Kg} \text { ha-1) }\end{array}$} & \multicolumn{2}{|c|}{$\begin{array}{l}\text { Seed index } \\
\text { (g/100 seeds) }\end{array}$} & \multirow{2}{*}{$\begin{array}{c}\% \text { increase } \\
\text { over } \\
\text { control (FP) }\end{array}$} \\
\hline & & & $\mathbf{R P}$ & FP & $\mathbf{R P}$ & FP & RP & FP & \\
\hline 2015-16 & NRCDR-02 & 2600 & 12 & 17 & 1491 & 1060 & 0.8 & 0.6 & 32.62 \\
\hline 2016-17 & NRCDR-02 & 2600 & 13 & 16 & 1780 & 1186 & 0.8 & 0.5 & 19.56 \\
\hline 2017-18 & NRCDR-02 & 2600 & 12 & 17 & 1726 & 1196 & 0.8 & 0.6 & 22.00 \\
\hline Average & - & 2600 & 12.33 & 13.33 & 1666 & 1147 & 0.8 & 0.56 & 24.72 \\
\hline
\end{tabular}

RP: Recommended Practice

FP: Farmers Practice

Table.3 Economical comparison between recommended practice and farmers practice

\begin{tabular}{|c|c|c|c|c|c|c|c|c|}
\hline \multirow{2}{*}{ Year } & \multicolumn{2}{|c|}{ Gross cost $($ Rs.ha-1) } & \multicolumn{2}{|c|}{ Gross return $\left(\right.$ Rs. ha $\left.{ }^{-1}\right)$} & \multicolumn{2}{|c|}{ Net return(Rs. ha $\left.{ }^{-1}\right)$} & \multicolumn{2}{c|}{ B: C Ratio } \\
\cline { 2 - 10 } & RP & FP & RP & FP & RP & FP & RP & FP \\
\hline $2015-16$ & $\mathbf{2 2 0 8 1}$ & $\mathbf{1 9 4 5 0}$ & $\mathbf{4 5 5 4 1}$ & $\mathbf{3 4 6 7 7}$ & $\mathbf{2 3 4 6 0}$ & $\mathbf{1 5 2 2 7}$ & $\mathbf{2 . 0 6}$ & $\mathbf{1 . 7 8}$ \\
\hline $2016-17$ & $\mathbf{2 1 9 8 4}$ & $\mathbf{1 9 8 5 9}$ & $\mathbf{6 3 8 2 0}$ & $\mathbf{4 2 2 3 1}$ & $\mathbf{4 1 8 3 6}$ & $\mathbf{2 2 3 7 2}$ & $\mathbf{2 . 9 1}$ & $\mathbf{2 . 1 2}$ \\
\hline $2017-18$ & $\mathbf{2 1 8 2 0}$ & $\mathbf{2 0 6 5 1}$ & $\mathbf{6 4 7 2 5}$ & $\mathbf{4 4 8 5 0}$ & $\mathbf{4 5 9 0 5}$ & $\mathbf{2 5 9 9 9}$ & $\mathbf{2 . 9 6}$ & $\mathbf{2 . 1 7}$ \\
\hline Average & $\mathbf{2 1 9 6 1}$ & $\mathbf{1 9 9 8 7}$ & $\mathbf{5 8 0 2 9}$ & $\mathbf{4 0 5 8 6}$ & $\mathbf{3 7 0 6 7}$ & $\mathbf{2 1 1 9 9}$ & $\mathbf{2 . 6 4}$ & $\mathbf{2 . 0 2}$ \\
\hline
\end{tabular}

Table.4 Impact of technological intervention on pest infestation

\begin{tabular}{|c|c|c|c|c|c|c|}
\hline \multirow{2}{*}{ Year } & \multicolumn{2}{|c|}{ Disease affected plants M-2 } & \multicolumn{2}{|c|}{ Damage \% } & \multicolumn{2}{c|}{ Infected pods (No/plant) } \\
\cline { 2 - 7 } & RP & FP & RP & FP & RP & $\mathbf{1 . 6}$ \\
\hline $2015-16$ & $\mathbf{3 . 2}$ & $\mathbf{6 . 4}$ & $\mathbf{9 . 3 1}$ & $\mathbf{1 6 . 1 0}$ & $\mathbf{7 . 4}$ & $\mathbf{9 . 6}$ \\
\hline $2016-17$ & $\mathbf{4 . 6}$ & $\mathbf{7 . 3}$ & $\mathbf{9 . 4 5}$ & $\mathbf{1 7 . 6 1}$ & $\mathbf{2 . 3}$ & $\mathbf{6 . 9}$ \\
\hline $2017-18$ & $\mathbf{5 . 3}$ & $\mathbf{7 . 2}$ & $\mathbf{1 0 . 4 6}$ & $\mathbf{1 7 . 7 4}$ & $\mathbf{2 . 5 3}$ & $\mathbf{7 . 9 6}$ \\
\hline Average & $\mathbf{4 . 3 6}$ & $\mathbf{6 . 9 6}$ & $\mathbf{9 . 7 4}$ & $\mathbf{1 7 . 1 5}$ & & \\
\hline
\end{tabular}


Table.5 Impact of CFLDs on Extension, technology gap and yield index

\begin{tabular}{|c|c|c|c|}
\hline Year & Extension gap $\left(\mathrm{kg} \mathrm{ha}^{-1}\right)$ & Technology gap $\left(\mathrm{kg} \mathrm{ha}^{-1}\right)$ & Technology index $(\%)$ \\
\hline $2015-16$ & $\mathbf{4 3 1}$ & $\mathbf{7 2 2}$ & $\mathbf{3 2 . 6 2}$ \\
\hline $2016-17$ & $\mathbf{5 9 4}$ & $\mathbf{4 3 3}$ & $\mathbf{1 9 . 5 6}$ \\
\hline $2017-18$ & $\mathbf{5 3 0}$ & $\mathbf{4 8 7}$ & $\mathbf{2 2 . 0 0}$ \\
\hline Average & $\mathbf{5 1 8}$ & $\mathbf{5 4 7}$ & $\mathbf{2 4 . 7 2}$ \\
\hline
\end{tabular}

\section{Insect infestation}

During the study, data as recorded (table 4) on infestation of Aphids caused premature dry and shading of pods. Spraying of Dimethoate 30 EC @ $1200 \mathrm{ml} / \mathrm{ha}$ Water at the time of pod initiation caused lesser pods infected (2.53) as compared to farmers' practices (7.96). Similar results quoted by Hossain et al., (2010).

\section{Extension gap, technology gap and yield index}

Data presented in table 5 showed the variation in extension gap and it varied from 431- 594 $\mathrm{kg}$ ha-1 with its averaged $518 \mathrm{~kg} \mathrm{ha}^{-1}$. Variations in technology gap $(433-722 \mathrm{~kg}$ ha-1) reflected the impact of recommended technology used in front line demonstrations in subsequent years. Fluctuations in technology gap as observed may be due to several biotic and abiotic factors. These results are in close conformity with the findings of Mitra and Samajdar (2010).

Yield index showed the feasibility of the evolved technology at the farmers' fields. Lower value of yield index meant more feasibility of disseminated technology (inverse relations). Variations in technology index during the FLDs were found 19.56 $32.62 \%$ however; its average of three year was $24.72 \%$ (table 5).Variations in yield index may be due to variations in soil fertility, environmental hazards and infestation of pest. The reduction in yield index (19.56) is good indicator of increased feasibility of demonstrated technology in these demonstrations and it can be gainful proposition for the farmers of the district and region as well. The results corroborated with the findings reported by Sagar and Chandra (2004).

\section{References}

Katare, Subhash, Pandey, SK and Mustafa, Mohd. 2011. Yield gap analysis of Rapeseed-mustard through front line demonstrations. Agric Update 6:5-7.

Chand, H. and Khirbat, S.K. (2009). Chickpea wilt and its management - a review. Agric. Rev., 30 (1):1-12 Table 5: Impact of FLDs on Extension, technology gap and yield index

Deshmukh, K. K., Saraiya, A.B. and Dubey, D.P. (2005). Effect of integrated nutrient management on productivity trends, economics and soil fertility in soybean-chickpea cropping system. JNKVV Res. J. 39 (2): 29-32.

Hossain Altaf, Haque Azizul, Ahmad Masum and Prodhan M.Z.H. (2010). Development of an integrated management approach for pod borer, Helicoverpa armigera (Hubner) on chickpea. Bangladesh J. Agril. Res. 35(2): 201-206.

Mitra Biplab, and Samajdar, T. (2010). Yield gap analysis of rapeseed- mustard through FLD. Agricultural Extension Review, April-June., 16-17.

Nene, Y.L., Mengistu A., Sinclair, J.B. and Royse, D.J. (1978). An annotated bibliography of chickpea diseases, Information bulletin No.1. Pp 1-53.

Sagar, R., L. and Ganesh, Chandra (2004). Front line demonstration on seasame in West Bengal. Agricultural Extension Review, 16 (2): 7-10. 
Samui, S., K. Maitra, S., Roy, D., K. Mandal, A., K. and Saha, D. (2003). Evaluation of front line demonstration on ground nut. Journal of the Indian Society Coastal Agricultural Research, 18 (2): 180-183.

Tiwari, K., B. and Saxena, A. (2001). Economic analysis of FLD of oil seed in Chhindwara. Bhartiya Krishi Anusandhan Patrika, 16 (3\&4): 185189.

Tiwari, R.B., Singh, Vinay and Parihar, Pushapa. (2003). Role of FLD in transfer of gram production technology. Maharashtra J. of Ext. Edu., 22 (1): 19.

Kiresur, VR, Ramanna Rao, SV and Hedge, DM. 2001. Improved technologies in oilseeds in oilseeds production-An assessment of their economic potentials in India. Agril Economic Res Rev, 14: 95-108.

Tomer, L.S., Sharma, B.P. and Joshi, K. (2003). Study on yield gap and adoption level of potato production technology in grid region. Maharashtra J. of Ext. Edu., 22 (1): $15-18$

omer, L.S., Sharma, B.P. and Joshi, K. (2003). Impact of front line demonstration of soybean in transfer of improved technology. Journal of Ext. Edu., 22 (1):139.

Venkattakumar, R., Ramanarao, S.V., Padmaiah, M. and Madhuri, P. (2010). Production constraints and information needs growers in Andhra Pradesh. Agri. Extn. Review, AprilJune: pp 21-24.

\section{How to cite this article:}

Hrish Kumar Rachhoya, Mukesh Sharma and Kana Ram Sodh. 2018. Evaluation of Yield Performance of Mustard (Brassica juncea) through Cluster Front Line Demonstration. Int.J.Curr.Microbiol.App.Sci. 7(07): 500-505. doi: https://doi.org/10.20546/ijcmas.2018.707.061 